\title{
Effectiveness and Safety of Tenofovir Disoproxil Fumarate in Chronic Hepatitis B: A 3-Year, Prospective, Real-World Study in France
}

\author{
Patrick Marcellin ${ }^{1}$ Fabien Zoulim ${ }^{2} \cdot$ Christophe Hézode $^{3} \cdot$ Xavier Causse $^{4}$. \\ Bruno Roche $^{5}$ - Régine Truchi ${ }^{6}$ - Arnaud Pauwels ${ }^{7}$ Denis Ouzan ${ }^{8}$. \\ Jérôme Dumortier $^{9}$ - Georges-Philippe Pageaux ${ }^{10}$ • Marc Bourlière ${ }^{11}$. \\ Ghassan Riachi $^{12}$ - Jean-Pierre Zarski ${ }^{13}$ - Jean-François Cadranel ${ }^{14}$. \\ Valérie Tilliet $^{15}$. Christiane Stern ${ }^{15}$ - Pascal Pétour ${ }^{15}$. Olivier Libert ${ }^{15}$. \\ Silla M. Consoli ${ }^{16} \cdot$ Dominique Larrey $^{10}$
}

Received: 26 June 2015/ Accepted: 28 December 2015/Published online: 28 January 2016

(C) The Author(s) 2016

\begin{abstract}
Background and Aims Tenofovir disoproxil fumarate (TDF) demonstrated potent and sustainable antiviral efficacy and a good safety profile in patients with chronic hepatitis B (CHB) in controlled clinical trials. Real-world data are important to confirm effectiveness and safety data
\end{abstract}

On behalf of the VIREAL Group. The list of members in the group is given in the Appendix section.

\section{Patrick Marcellin}

patrick.marcellin@bjn.aphp.fr

Fabien Zoulim

fabien.zoulim@inserm.fr

Christophe Hézode

christophe.hezode@hmn.aphp.fr

Xavier Causse

xavier.causse@chr-orleans.fr

Bruno Roche

bruno.roche@pbr.aphp.fr

Régine Truchi

truchi.r@chu-nice.fr

Arnaud Pauwels

arnaud.pauwels@ch-gonesse.fr

Denis Ouzan

Denis.ouzan@wanadoo.fr

Jérôme Dumortier

jerome.dumortier@chu-lyon.fr

Georges-Philippe Pageaux

gp-pageaux@chu-montpellier.fr

Marc Bourlière

mbourliere@hopital-saint-joseph.fr in patient populations encountered in routine clinical practice.

Methods This non-interventional, prospective, 36-month study included treatment-naïve and treatment-experienced patients with CHB initiating their first TDF regimen (monotherapy or combination therapy) in routine clinical practice in France. Clinical, virologic, biochemical, compliance, and safety data were collected.

Results Data from 440 consecutive patients from 58 centers were analyzed. The majority of the cohort was male

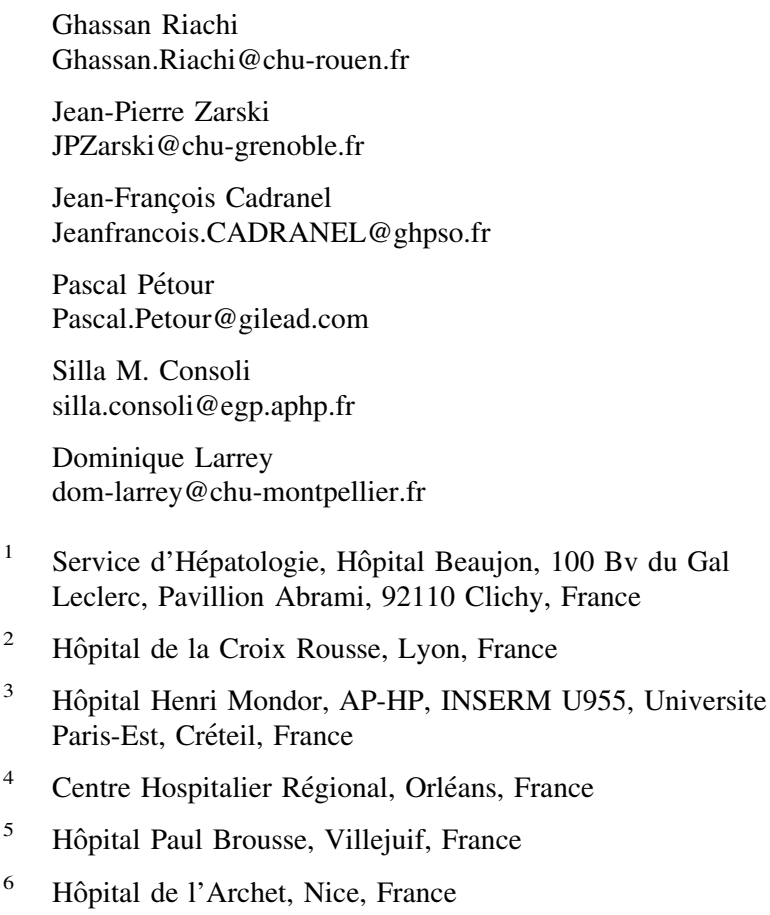


(71\%), hepatitis B "e" antigen-negative (HBeAg-) (74\%), and treatment-experienced (56\%); $11 \%$ were aged $\geq 65$ years; and comorbidities were reported in $39 \%$. After 12 months, $92 \%$ of the overall cohort achieved virologic response (HBV DNA $<69 \mathrm{IU} / \mathrm{mL}$ ) which was maintained to 36 months (96\%); virologic response was achieved by $>90 \%$ of patients irrespective of $\mathrm{HBeAg}$ status, age, or prior treatment history. At 36 months, $77 \%$ of patients had normal alanine aminotransferase levels. Fourteen patients lost hepatis B surface (HBs) antigen, and seven seroconverted to anti-HBs. TDF was well tolerated over the 36-month study, including in 14 women who became pregnant during the study. Median estimated glomerular filtration rate did not change markedly from baseline irrespective of prior treatment history.

Conclusions TDF demonstrated potent virologic and biochemical responses across a broad range of patients reflective of routine clinical practice. The safety profile was consistent with results from pivotal trials.

Keywords HBV - Tenofovir - Routine practice - Realworld

\section{Introduction}

Chronic infection with hepatitis B virus (HBV) represents a major global health problem, responsible for around 780,000 deaths worldwide, largely through serious liverrelated sequelae [1]. Chronic HBV infection (CHB) prevalence varies widely, being highest in sub-Saharan Africa and East Asia, where 5-10\% of the adult population is chronically infected. HBV infection is becoming a public health concern in countries where prevalence was previously reduced due to factors including increased migration from countries with intermediate/high $\mathrm{HBV}$ prevalence [2]. Although recent data on HBV prevalence in France are lacking, a 2004 national survey estimated hepatitis B surface antigen ( $\mathrm{HBsAg}$ ) prevalence was $0.68 \%$, corresponding to 280,821 chronic carriers [3]. A 2001

\footnotetext{
7 Centre Hospitalier, Gonesse, France

8 Institut Arnault Tzanck, Saint Laurent Du Var, France

9 Hôpital Edouard Hériot, Lyon, France

10 Hôpital Saint Eloi, Montpellier, France

11 Hôpital Saint Joseph, Marseille, France

12 Hôpital Charles Nicolle, Rouen, France

13 Hôpital de la Tronche, Grenoble, France

14 Centre Hospitalier Laennec, Creil, France

15 Gilead Sciences, Boulogne-Billancourt, France

16 Hôpital Européen Georges Pompidou, Paris, France
}

French survey of patient mortality related to hepatitis B and $\mathrm{C}$ estimated that 1507 deaths were attributed to $\mathrm{HBV}$ infection, corresponding to 2.5 deaths per 100,000 persons [4].

Many studies have demonstrated the correlation between viral load and the risk of developing cirrhosis and hepatocellular carcinoma (HCC) [5-8]. As it is not possible to eradicate $\mathrm{HBV}$ [9], $\mathrm{CHB}$ treatment aims to provide sustained suppression of HBV replication, thus preventing disease progression and death. Tenofovir disoproxil fumarate (TDF) is a potent nucleotide analog recommended as a first-line therapy for CHB in international and national guidelines [9-11]. Pivotal randomized controlled trials have reported high efficacy and a favorable safety profile with TDF treatment for up to 8 years in treatmentnaïve and treatment-experienced patients [12-15], with associated fibrosis regression and cirrhosis [14]. No drug resistance to TDF has been observed.

Published data from real-world studies with TDF, which include the highly diverse patients encountered in routine practice, are lacking, and are mostly retrospective, but are required in order to confirm and expand upon the results of clinical trials $[16,17]$. The prospective, non-interventional, multicenter VIREAL study investigated the use of TDF in routine clinical management of $\mathrm{CHB}$ in France, and evaluated its effectiveness and safety in a "real-world" cohort of patients.

\section{Patients and Methods}

VIREAL is a multicenter, non-interventional, prospective study to assess the long-term effectiveness and safety of TDF treatment in a real-life cohort of patients with $\mathrm{CHB}$ managed in routine clinical settings in France. Participating sites included teaching hospitals, general hospitals, and private practices specializing in $\mathrm{CHB}$ to provide a representative cross section of $\mathrm{CHB}$ management. Patients were enrolled at 58 centers across France. Recruitment took place between June 2009 and April 2010, and the database was locked in October 2013.

The study was conducted in accordance with Good Epidemiological Practice guidelines, was approved by the French Medical Board, and was authorized by the National Computers and Privacy Commission. Patients gave written consent for the collection of anonymized medical data from their medical files.

\section{Study Population}

The study enrolled treatment-naïve or treatment-experienced patients $\geq 18$ years of age with hepatitis $\mathrm{B}$ " $\mathrm{e}$ " antigen ( $\mathrm{HBeAg}$ )-negative ( $\mathrm{HBeAg}-$ ) or $\mathrm{HBeAg}$-positive 
$(\mathrm{HBeAg}+) \mathrm{CHB}$, initiating a first prescription of TDF at enrollment. TDF treatment initiation was at the treating physician's discretion. Key exclusion criteria included prior treatment with TDF, evidence of HCC, or co-infection with human immunodeficiency virus (HIV), hepatitis $\mathrm{C}$ virus, or hepatitis $\mathrm{D}$ virus.

\section{Study Assessments and Data Collection}

Data on safety and on the clinical, laboratory, and virologic course of TDF-treated patients from the routine testing/ evaluations conducted by the treating physician were captured. Study-specific laboratory tests, resistance monitoring, or prespecified visits were not required. As visit times varied between practices, patient assessments were assigned a nominal visit month of $3,6,12,18,24,30$, and 36 months based on the number of days since the baseline visit within a visit window of \pm 3 months of the nominal visit month. Data were collected via an electronic case report form and included the following: patient demographics; anti-HBV treatment history; viral genotype; serum HBV DNA levels; $\mathrm{HBeAg}$ and $\mathrm{HBsAg}$; alanine aminotransferase (ALT); other routine laboratory parameters; renal function tests (serum creatinine, creatinine clearance $[\mathrm{CrCl}]$, estimated glomerular filtration rate [eGFR] calculated by Cockcroft-Gault formula at the beginning of the study which was replaced by the Chronic Kidney Disease Epidemiology Collaboration formula); liver histology and progression of liver-related complications; resistance to anti-HBV therapy; adverse events (AEs) and serious AEs; pregnancy; adherence to therapy; and therapy interruptions.

Virologic response was defined as HBV DNA <69 IU/ $\mathrm{mL}$. Adherence was assessed using a six-question questionnaire completed by the patient at each visit, which was first applied in the field of hypertension [18]. The total number of "yes" answers defined the level of adherence: $0=$ good; $1-2=$ minor problems; and $>3=$ poor adherence.

\section{Statistical Analysis}

Mean, standard deviation (SD), median, range, or first and third quartile (Q1, Q3) were calculated for continuous variables, together with the total number of observations and the number of non-missing and missing values. For categorical variables, number and percent of patients are reported. Missing data were excluded from the efficacy analysis. The safety analysis included all treated patients.

Comparative analyses were performed using Pearson's Chi-square test for qualitative variables, and Student's $t$ test for analyses of variance for quantitative variables. Nonparametric tests were used in the case of a non-normal distribution. Statistical analysis was performed using $\mathrm{SAS}^{\circledR}$ (Version 9.1).

\section{Results}

In total, 440 patients were prospectively enrolled. Of these, 328 completed the study, and 112 discontinued the study [49 (46.7\%) patients were lost to follow-up; $27(24.1 \%)$ were discontinued at the investigator's discretion; 12 (10.7\%) patients made the decision to discontinue; 10 patients died $(8.9 \%)$; seven $(6.3 \%)$ patients discontinued due to an adverse drug reaction; and seven $(6.3 \%)$ were withdrawn as they did not fit the inclusion/exclusion criteria].

The overall population was predominantly male and around three-quarters were $\mathrm{HBeAg}-$ (Table 1). The largest proportion of patients was of European decent (38.6\%). Mode of HBV infection was unknown in almost half of patients $(46 \%)$. Where this was known $(n=237)$, the most commonly cited routes were the following: at birth or during early childhood $(54.4 \%)$; family exposure (18.1\%); nosocomial infection $(10.5 \%)$; sexual exposure $(6.3 \%)$; and drug use $(2.5 \%)$.

Just over half of the patients $(n=258)$ were treatmentexperienced, with around two-thirds having previously received an adefovir (ADV)-containing regimen: monotherapy or in combination with lamivudine (LAM) (Table 2). The majority (179/258) of the treatment-experienced patients were switched directly to TDF. Seventynine patients were not receiving treatment at baseline and the washout period of previous treatment was variable. Of the treatment-experienced patients, $64(24.8 \%)$ terminated previous therapy and $38(14.7 \%)$ initiated TDF due to persistent viremia/suboptimal response and viral relapse (defined as a confirmed increase in HBV DNA level of more than $1 \log _{10} \mathrm{IU} / \mathrm{mL}$ compared with the nadir (lowest value) HBV DNA level on therapy) [9]. Mean baseline HBV DNA levels were lower in treatment-experienced patients than treatment-naïve patients (Table 2). A higher proportion of treatment-experienced patients had undetectable viral load (HBV DNA $<69 \mathrm{IU} / \mathrm{mL}$ ) at baseline compared with treatment-naïve patients (61.1 vs. $5.5 \%$, respectively, Table 2). Viral genotype was known for only $7 \%$ of patients so is not included in the analysis (Table 1).

Baseline ALT levels varied widely [median (range) 35 (7-828) IU/Ml]. At baseline, more than half of patients had normal ALT (ALT <upper limit of normal) (Table 2). The proportion of patients with normal ALT was higher in treatment-experienced compared with treatment-naïve patients (71.3 vs. $35.3 \%$, respectively), and in $\mathrm{HBeAg}-$ compared with $\mathrm{HBeAg}+$ patients (59.5 vs. $42.9 \%$, respectively). 
Table 1 Baseline characteristics

\begin{tabular}{ll}
\hline Characteristic & $N=440$ \\
\hline Age, years, mean (SD) & $45.3(14.3)$ \\
$\geq 65$ years, $n(\%)$ & $48(10.9)$ \\
Male, $n(\%)$ & $312(70.9)$ \\
Geographic descent, $n(\%)$ & \\
Europe & $170(38.6)$ \\
Middle East & $21(4.8)$ \\
Asia Pacific & $101(23.0)$ \\
North Africa & $44(10.0)$ \\
Sub-Saharan Africa & $87(19.8)$ \\
North and South America & $11(2.5)$ \\
Unknown & $6(1.4)$ \\
Genotype, $n(\%)$ & \\
A & $4(0.9)$ \\
B & $5(1.1)$ \\
C & $7(1.6)$ \\
D & $9(2.0)$ \\
E & $5(1.1)$ \\
Missing & $410(93.2)$ \\
Patients with cirrhosis, $n(\%)^{\mathrm{a}}$ & $68(15.5)$ \\
Liver biopsy performed, $n(\%)$ & $298(67.7)$ \\
Fibrosis stage (METAVIR), $n(\%)$ & \\
F0-F1 & $104(23.6)$ \\
F2 &
\end{tabular}

$S D$ standard deviation

${ }^{a}$ History of cirrhosis as defined by the investigator; method not further specified

b Where reported $(n=170)$. Multiple comorbidities were possible

Around two-thirds of patients had a report of liver biopsy at baseline. The majority had no/minimal fibrosis (METAVIR score F0-F1) or moderate fibrosis (F2); $14.4 \%$ had cirrhosis (F4). Clinical signs of cirrhosis were reported in 17 patients (co-existing signs were possible): ascites $(n=4)$, esophageal varices $(n=13)$, and splenomegaly $(n=10)$.
The most commonly reported comorbidities were hypertension and diabetes mellitus; prior renal insufficiency was reported in 14 patients, and 14 patients had a history of liver $(n=11)$ or renal $(n=3)$ transplantation. In all, 122 patients $(27.7 \%)$ had baseline eGFR $<90 \mathrm{~mL} /$ $\min / 1.73 \mathrm{~m}^{2}$, with 24 of these patients having a baseline eGFR $<60 \mathrm{~mL} / \mathrm{min} / 1.73 \mathrm{~m}^{2}$; no patient had baseline eGFR $<30 \mathrm{~mL} / \mathrm{min} / 1.73 \mathrm{~m}^{2}$.

\section{TDF Treatment}

At study initiation, most treatment-naïve patients (91.2\%) received TDF as monotherapy, with the remainder receiving TDF in combination with LAM. The majority of treatment-experienced patients $(63.4 \%)$ received initial treatment with TDF as monotherapy, with the remainder receiving TDF in combination with entecavir (ETV) $(19.8 \%)$ or LAM $(21.3 \%)$. Most patients remained on TDF monotherapy for the entire study duration, with 70 receiving add-on medication, predominantly $\operatorname{ETV~}(n=15)$ or LAM $(n=45)$. Overall 17 patients switched to an alternative treatment (ETV $n=14$; LAM $n=3)$.

\section{Virologic Response}

By month $12,92 \%$ of the overall population with available data $(n=308)$ had HBV DNA $<69 \mathrm{IU} / \mathrm{mL}$, rising to $96 \%$ at 36 months $(n=259)$. A greater proportion of $\mathrm{HBeAg}-$ patients compared with $\mathrm{HBeAg}+$ patients achieved $\mathrm{HBV}$ DNA $<69 \mathrm{IU} / \mathrm{mL}$ by month 12 (90.0 vs. $80.3 \%$, respectively). Irrespective of $\mathrm{HBeAg}$ status, treatment history, or whether patients received TDF as monotherapy or in combination, $>90 \%$ of patients with available data achieved HBV DNA $<69 \mathrm{IU} / \mathrm{mL}$ by 36 months of treatment with TDF (Fig. 1; Table 3). Prior treatment regimen did not affect response; $>90 \%$ of patients who were previously treated with LAM $+\operatorname{ADV}(n=82)$ or with ETV $(n=21)$ achieved HBV DNA $<69 \mathrm{IU} / \mathrm{mL}$ by month 36 . A total of 27 patients had one or more resistance-associated variants (RAVs) at baseline, including those associated with LAM and ADV. Three of these patients had HBV DNA $<69 \mathrm{IU} / \mathrm{mL}$ at baseline and at final visit; all remaining patients achieved a virologic response during treatment, the majority by month 3 , and maintained this response to their last visit. Of the 18 patients with resistance-associated mutations at baseline and HBV DNA levels available at baseline and final visit, 13 had undetectable HBV DNA at the final visit. No correlation was observed between adherence score and virologic response. Older age did not appear to affect response; of the 26 patients aged $\geq 65$ years at baseline who completed 36 months of treatment, all (100\%) achieved HBV DNA 
Table 2 Baseline characteristics by prior treatment history

\begin{tabular}{|c|c|c|c|}
\hline Characteristic & Treatment-naïve patients & Treatment-experienced patients & All patients \\
\hline$n / N(\%)$ & $182 / 440(41.4)$ & $258 / 440(58.6)$ & $440 / 440(100)$ \\
\hline HBeAg-negative, $n / n(\%)$ & $121 / 419(28.9)$ & $183 / 419(43.7)$ & $304 / 419(74.1))$ \\
\hline HBV DNA, IU/mL, mean (SD) & $3.41 \times 10^{7}\left(1.15 \times 10^{8}\right)$ & $3.76 \times 10^{6}\left(2.05 \times 10^{7}\right)$ & $1.63 \times 10^{7}\left(7.70 \times 10^{7}\right)$ \\
\hline HBV DNA, IU/mL, median $(\mathrm{Q} 1-\mathrm{Q} 3)^{\mathrm{a}}$ & $4.1 \times 10^{4}\left(2270-6.8 \times 10^{6}\right)$ & $20(12-735)$ & $3.6 \times 10^{3}\left(40.0-3.95 \times 10^{5}\right)$ \\
\hline HBV DNA $\geq 2000 \mathrm{IU} / \mathrm{mL}, n / n(\%)$ & 36/181 (19.9) & $16 / 257(6.2)$ & $52 / 438(11.9)$ \\
\hline Normal ALT $\left(\leq \mathrm{ULN}^{\mathrm{b}}\right), n / n(\%)$ & $61 / 171(35.3)$ & $179 / 251(71.3)$ & $240 / 422(56.9)$ \\
\hline HBV DNA $<69 \mathrm{IU} / \mathrm{mL}, n / n(\%)$ & $10 / 182(5.5)$ & $157 / 258(60.9)$ & $167 / 440(38.0)$ \\
\hline \multicolumn{4}{|l|}{ Prior treatment regimen, $n(\%)^{\mathrm{c}}$} \\
\hline IFN or PEG-IFN \pm other & - & $68 / 258(28.3)$ & - \\
\hline LAM monotherapy & - & $28 / 258(9.7)$ & - \\
\hline ADV monotherapy & - & $21 / 258(6.6)$ & - \\
\hline ETV monotherapy & - & $13 / 258(4.7)$ & - \\
\hline $\mathrm{LAM}+\mathrm{ADV}$ & - & $109 / 258(32.2)$ & - \\
\hline $\mathrm{LAM}+\mathrm{ADV}+$ other & - & $38 / 258(23.6)$ & - \\
\hline Other $^{\mathrm{d}}$ & - & $7 / 258(7.4)$ & - \\
\hline \multicolumn{4}{|l|}{ Reason for initiating TDF, $n(\%)$} \\
\hline Persistent viremia/suboptimal response & - & $64 / 258(24.8)$ & - \\
\hline Relapse & - & $38 / 258(14.7)$ & - \\
\hline Resistance development & - & $9 / 258(3.5)$ & - \\
\hline Adverse reaction & - & $10 / 258(3.9)$ & - \\
\hline Non-adherence & - & $5 / 258(1.9)$ & - \\
\hline Other (not specified) & - & $141 / 258(54.7)$ & - \\
\hline \multicolumn{4}{|l|}{ Laboratory and biochemical parameters } \\
\hline Serum creatinine, median (range), $\mu \mathrm{mol} / \mathrm{L}$ & $77.0(37.0,1034.0)$ & $83.0(29.0,416.0)$ & $79.70(29.0,197.4)$ \\
\hline $\mathrm{CrCl}$, median (range), $\mathrm{mL} / \mathrm{min}$ & $112.9(52.4,226.0)$ & $90.5(29.3,200.9)$ & $98.8(29.3,226.0)$ \\
\hline eGFR, median (range), $\mathrm{mL} / \mathrm{min} / 1.73 \mathrm{~m}^{2}$ & $107.7(56.5,148.2)$ & $91.7(33.3,149.7)$ & $99.1(33.3,149.7)$ \\
\hline ALT, median (range), U/L & $59.0(7.0,2174.0)$ & $29.0(8.0,521.0)$ & $35.0(7.0,828.0)$ \\
\hline
\end{tabular}

$A D V$ adefovir, $A L T$ alanine aminotransferase, $C r C l$ creatinine clearance, $e G F R$ estimated glomerular filtration rate, $H B e A g$ hepatitis B "e" antigen, ETV entecavir, IFN interferon, $L A M$ lamivudine, $P E G-I F N$ pegylated interferon, $S D$ standard deviation, TDF tenofovir disoproxil fumarate, $U L N$ upper limit of normal

a Data were missing for one patient in the treatment-naïve group and one patient in the treatment-experienced group

b ALT upper limit of normal was $\leq 43 \mathrm{U} / \mathrm{L}$ for males and $\leq 34$ for females

c Multiple responses possible; 26 patients are included in both the interferon-containing regimen and LAM + ADV + other group

${ }^{\mathrm{d}}$ Includes unspecified treatment and treatment with telbivudine + ADV, ETV + ADV, and ETV + LAM

$<69 \mathrm{IU} / \mathrm{mL}$ versus $95.3 \%$ of patients aged $<65$ years $(n=222)$.

Among 167 patients with HBV DNA $<69 \mathrm{IU} / \mathrm{mL}$ at baseline, 13 patients experienced virologic breakthrough (defined as patients with baseline HBV DNA $<69$ IU/mL and an HBV DNA of $\geq 69 \mathrm{IU} / \mathrm{mL}$ for at least one postbaseline visit) over the course of the study. The annual rate of virologic breakthrough was 3.6, 3.6, and $0.6 \%$ at 12,24 , and 36 months, respectively. For 11 of these 13 patients, breakthrough was transient. All patients with virologic breakthrough continued TDF and completed the study. No baseline RAVs were reported for the 13 patients with virologic breakthrough. A minor problem of compliance was reported for four patients, and the treatment adherence questionnaire was not completed for eight patients.

\section{Biochemical Response}

Mean (SD) ALT improved from 67.2 (95.07) IU/mL at baseline to $31.3(18.01) \mathrm{IU} / \mathrm{mL}$ at month 36 . The proportion of patients with normal ALT levels increased steadily to $76.8 \%$ (74.6\% treatment-naïve; $77.7 \%$ treatment-experienced) by 12 months, and this proportion was maintained to 36 months $(78.0 \%$ overall; $75.0 \%$ treatmentnaïve; $79.4 \%$ treatment-experienced). 
(A)

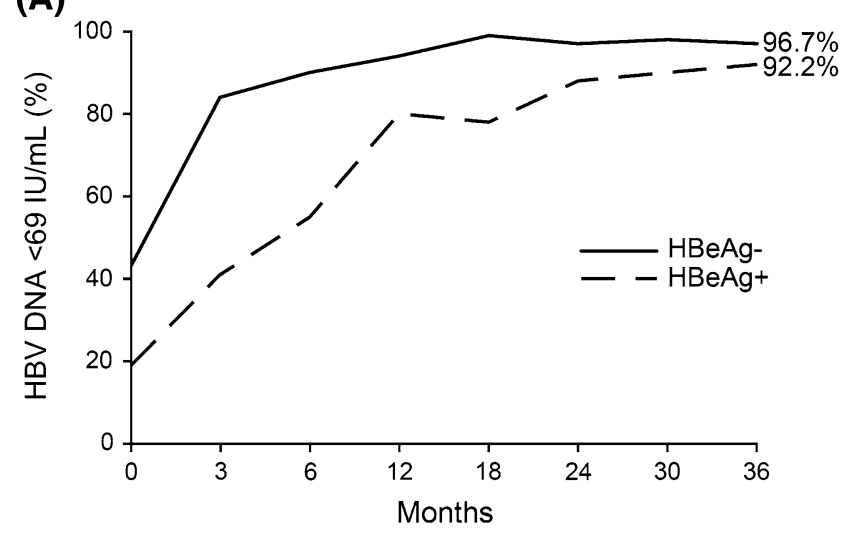

Patients with available data

$\begin{array}{lrrrrrrr}\text { HBeAg+ } 106 & 79 & 80 & 66 & 73 & 74 & 68 & 64 \\ \text { HBeAg- } 304 & 225 & 229 & 227 & 200 & 198 & 185 & 183\end{array}$
(B)

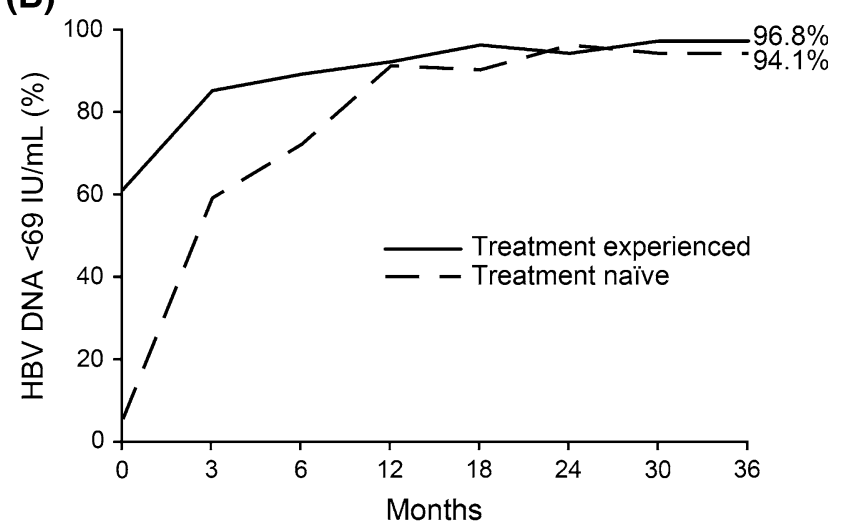

Patients with available data

$\begin{array}{lllllllll}\begin{array}{l}\text { Treatment } \\ \text { experienced }\end{array} & 257 & 184 & 184 & 189 & 170 & 171 & 158 & 158 \\ \begin{array}{l}\text { Treatment } \\ \text { naïve }\end{array} & 181 & 139 & 142 & 119 & 114 & 110 & 104 & 101\end{array}$

Fig. 1 Virologic response over time. a By HBeAg status; b by prior treatment status. HBeAg hepatitis B e antigen

Table 3 Proportion of patients achieving virologic response (HBV DNA $<69 \mathrm{IU} / \mathrm{mL}$ ) according to therapy and HBV level at baseline

\begin{tabular}{lcccc}
\hline Baseline treatment/treatment group & Baseline & Month 12 & Month 24 & Month 36 \\
\hline $\begin{array}{l}\text { Treatment-naïve patients }(n=182), n(\%) \\
\text { TDF monotherapy }\end{array}$ & $10(6)$ & $99(91)$ & $104(96)$ & $94(95)$ \\
All $(n=166)$ & $10(100)$ & $5(100)$ & $3(100)$ & $3(100)$ \\
HBV DNA $<69 \mathrm{IU} / \mathrm{mL}$ at BL $(n=11)$ & $0(0)$ & $94(90)$ & $101(96)$ & $91(95)$ \\
HBV DNA $>69 \mathrm{IU} / \mathrm{mL}$ at BL $(n=155)$ & & & \\
TDF combination therapy & $0(0)$ & $8(89)$ & $4(100)$ & $2(67)$ \\
HBV DNA $>69 \mathrm{IU} / \mathrm{mL}$ at BL $(n=16)$ & & & \\
Treatment-experienced patients $(n=258), n(\%)$ & & & \\
TDF monotherapy & $90(55)$ & $99(89)$ & $95(94)$ & $94(96)$ \\
All $(n=166)$ & $90(100)$ & $58(97)$ & $52(96)$ & $51(96)$ \\
HBV DNA $<69 \mathrm{IU} / \mathrm{mL}$ at BL $(n=91)$ & $0(0)$ & $41(80)$ & $43(91)$ & $43(96)$ \\
HBV DNA $>69 \mathrm{IU} / \mathrm{mL}$ at BL $(n=75)$ & & & & \\
TDF combination therapy & $67(73)$ & $76(96)$ & $63(93)$ & $58(98)$ \\
All $(n=92)$ & $67(100)$ & $55(98)$ & $49(94)$ & $44(100)$ \\
HBV DNA $<69 \mathrm{IU} / \mathrm{mL}$ at BL $(n=67)$ & $0(0)$ & $21(91)$ & $14(88)$ & $14(93)$ \\
HBV DNA $>69 \mathrm{IU} / \mathrm{mL}$ at BL $(n=25)$ &
\end{tabular}

$B L$ baseline, $T D F$ tenofovir disoproxil fumarate

\section{Serologic Response}

Of the 80 patients who were $\mathrm{HBeAg}+$ at baseline with $\geq 1$ additional $\mathrm{HBeAg}$ status test at some stage during the study, 36 (45\%) lost $\mathrm{HBeAg}$ and 20 achieved $\mathrm{HBeAg}$ seroconversion during the study (five additional patients were anti-HBe+ at baseline). Three patients who lost $\mathrm{HBe} \mathrm{Ag}$ and seroconverted to anti-HBe+ during the study reconverted and were $\mathrm{HBeAg}+$, anti-HBe - at their final study visit.
During the study, 14 patients (3\%) lost HBsAg. (Three $\mathrm{HBeAg}+$ at baseline, $10 \mathrm{HBeAg}-$, and one with unknown HBeAg status at baseline). Of the 14 patients with HBsAg loss, five were treatment-naïve and nine were treatmentexperienced $(\mathrm{ADV}+\mathrm{LAM}, n=4 ; \mathrm{ADV}+\mathrm{LAM}+-$ PEG-IFN,$\quad n=2 ;$ ADV + PEG-IFN,$\quad n=2 ; \quad$ ADV + ETV, $n=1)$. The cumulative rate of HBsAg loss was $0.96 \%$ in the first year, $2.89 \%$ in year 2, and $3.37 \%$ in year 3. Seven patients (Five $\mathrm{HBeAg}_{-}$) achieved $\mathrm{HBsAg}$ seroconversion during the course of the study. The 
cumulative rate of seroconversion was $0.72 \%$ in the first year, $1.20 \%$ in year 2 , and $1.68 \%$ in year 3 .

\section{Safety}

TDF was well tolerated over the 36-month study. In total, 41 patients $(9.3 \%)$ reported 68 AEs considered by the physician to be related to TDF (Table 4). There was no difference in the proportions of treatment-naïve and treatment-experienced patients reporting adverse events (8.2 vs. $10.1 \%, P=0.711$ ). Of the 16 serious AEs reported in 16 patients, nine were considered to be related to TDF (visual impairment, nausea, asthenia, gait disturbance, weight decrease, muscular weakness, musculoskeletal pain, depression, psoriasis, all $n=1$ ).

Table 4 Adverse events considered by the physician to be related to TDF

Patients $(n)$

Number of adverse events/patient

1

$\leq 2$ 27

$\leq 3$

36

$\leq 8$

39

Serious adverse events ${ }^{\mathrm{a}}$

Adverse events occurring in $>1$ patient

$\begin{array}{lr}\text { Abdominal pain } & \text { b } \\ \text { Asthenia } & 8 \\ \text { Nausea } & 7 \\ \text { Vomiting } & 6 \\ \text { Diarrhea } & 5 \\ \text { Hypophosphatemia } & 5 \\ \text { Headache/migraine } & 4 \\ \text { Renal related } & 2 \\ \quad \text { Abnormal renal function tests } & \\ \text { Renal failure } & 4 \\ \quad \text { Renal impairment } & 3 \\ \text { Renal tubular disorder } & 2 \\ \text { Muscle spasms } & 2 \\ \text { Discontinuation of TDF due to adverse events }{ }^{\mathrm{d}} & 23\end{array}$

$T D F$ tenofovir disoproxil fumarate

a Serious adverse events comprised visual impairment, nausea, asthenia, gait disturbance, weight decrease, muscular weakness, musculoskeletal pain, depression, psoriasis, (all $n=1$ )

b Abdominal pain includes the MedRA preferred terms abdominal pain upper $(n=1)$ and abdominal pain $(n=7)$

c Abnormal results included creatinine renal clearance decreased $(n=2)$ and blood creatinine increased $(n=2)$

${ }^{\mathrm{d}}$ Reasons for discontinuation in $>1$ patient (multiple reasons per patient were possible): nausea $(n=5)$ vomiting $(n=4)$; asthenia $(n=3)$; renal failure $(n=3)$; diarrhea $(n=2)$; abdominal pain $(n=2)$; renal impairment $(n=2)$; renal tubular disorder $(n=2)$
There were 10 deaths during the study [HCC $n=1$; leukemia $n=2$; breast cancer $n=1$; suicide post-liver transplantation $n=1$; stroke $n=1$; post-liver transplantation complications $n=1$; cholangiocarcinoma $n=1$; and end-stage liver disease (hepatic encephalopathy $n=1$; spontaneous bacterial peritonitis $n=1$ )]. No deaths were considered to be related to TDF.

Sixteen pregnancies were reported during the study. The majority of these patients had become pregnant while taking TDF with one case where TDF was administered prophylactically. Follow-up data were available for 14 cases. Of these, the mean age of the mothers was 29 years, and $57 \%(n=8)$ were $\mathrm{HBeAg}+$; METAVIR fibrosis scores (where available) were F0 in one patient, F1 in three patients, and F2 in six patients. Median duration of TDF exposure during pregnancy was 35 weeks (range 5-39 weeks). Therapy was interrupted in four patients (obstetricians' decision $n=2$; patient's decision $n=1$; HBsAg loss $n=1$ ) at weeks 12, 16, 23, and 25 of pregnancy. One patient discontinued treatment at week 5 (obstetrician's decision). Two $\mathrm{HBeAg}+$ mothers had HBV DNA $>10^{6} \mathrm{IU} / \mathrm{mL}$ at delivery (one TDF discontinuation; one non-adherence). Vaccination and immunoprophylaxis according to the French guidelines were recommended for all newborns. Median gestational age at delivery was 39 weeks (range 34-40 weeks). No AEs related to TDF were observed, no neonatal complications arose, and no birth defects were reported. Complications during pregnancy, labor, or postpartum were: $n=1$; premature labor controlled by medication and $n=2$; postpartum hemorrhage. Five patients reported breastfeeding, with three breastfeeding while receiving TDF without any adverse consequences for the babies up to 1 year. No infant was reported to be $\mathrm{HBsAg}+$ at 9 months of age. Of five infants with anti-HBs testing, all were anti-HBs+ (84-308 IU/ $\mathrm{mL}$ ).

During the course of the study, median change in $\mathrm{CrCl}$ and serum creatinine remained relatively stable over 36 months of treatment, regardless of prior treatment (Table 5). Serum phosphorus levels were also stable over the study period.

Mean eGFR declined slightly over the treatment period (Table 6). Older patients ( $\geq 65$ years) and patients previously treated with ADV-containing regimens had lower eGFR at baseline, which declined slightly or remained stable over the treatment period (Fig. 2a). When subdivided by baseline eGFR, mean eGFR declined slightly over time in patients with baseline $\mathrm{CrCl} \geq 90 \mathrm{~mL} / \mathrm{min} / 1.73 \mathrm{~m}^{2}$, and increased slightly in patients with mild or moderate renal impairment at baseline (Fig. 2b). Overall, 65 (15\%) had a decline in eGFR of $\geq 20 \%$ versus baseline and 26 patients $(6 \%)$ had a decline in eGFR of $\geq 30 \%$ versus baseline (Table 7). Prior treatment did not have a 
Table 5 Mean change from baseline in creatinine clearance, serum creatinine, and serum phosphorus (all patients with available data)

\begin{tabular}{|c|c|c|c|c|}
\hline & Baseline & Month 12 & Month 24 & Month 36 \\
\hline \multicolumn{5}{|l|}{ Creatinine clearance $(n)$} \\
\hline \multicolumn{5}{|c|}{ Median (range) change from baseline ( $\mathrm{mL} / \mathrm{min})$} \\
\hline Overall & 352 & $\begin{array}{l}245 \\
-1.78 \\
(-65.80,44.81)\end{array}$ & $\begin{array}{l}213 \\
-1.11 \\
-82.13,50.65)\end{array}$ & $\begin{array}{l}200 \\
-3.26 \\
(-69.76,48.50)\end{array}$ \\
\hline Treatment-naive & 137 & $\begin{array}{l}88 \\
-2.45 \\
(-42.83,44.81)\end{array}$ & $\begin{array}{l}76 \\
2.42 \\
(-39.79,50.65)\end{array}$ & $\begin{array}{l}72 \\
-6.58 \\
(-61.56,46.34)\end{array}$ \\
\hline Treatment-experienced & 215 & $\begin{array}{l}157 \\
-1.48 \\
(-65.80,35.45)\end{array}$ & $\begin{array}{l}137 \\
-1.37 \\
(-82.13,49.94)\end{array}$ & $\begin{array}{l}128 \\
-1.85 \\
(-69.76,48.50)\end{array}$ \\
\hline \multicolumn{5}{|l|}{ Serum creatinine $(n)$} \\
\hline \multicolumn{5}{|c|}{ Median (range) change from baseline $(\mu \mathrm{mol} / \mathrm{L})$} \\
\hline Overall & 257 & $\begin{array}{l}249 \\
0.00 \\
(-44.00,81.20)\end{array}$ & $\begin{array}{l}217 \\
-0.8 \\
(-44.00,56.90)\end{array}$ & $\begin{array}{l}204 \\
0.74 \\
(-37.00,45.00)\end{array}$ \\
\hline Treatment-naive & 110 & $\begin{array}{l}92 \\
0.00 \\
(-23.00,28.90)\end{array}$ & $\begin{array}{l}80 \\
0.22 \\
(-27.80,38.00)\end{array}$ & $\begin{array}{l}76 \\
3.00 \\
(-34.00,619.20)\end{array}$ \\
\hline Treatment-experienced & 151 & $\begin{array}{l}159 \\
-0.44 \\
(-44.00,419.00)\end{array}$ & $\begin{array}{l}138 \\
-2.00 \\
(-44.00,56.90)\end{array}$ & $\begin{array}{l}130 \\
-0.75 \\
(-145.90,42.00)\end{array}$ \\
\hline \multicolumn{5}{|l|}{ Serum phosphorus $(n)$} \\
\hline \multicolumn{5}{|l|}{ Median (range) (mg/dL) } \\
\hline Overall & $\begin{array}{l}157 \\
1.01 \\
(0.51,1.56)\end{array}$ & $\begin{array}{l}185 \\
1.02 \\
(0.56,1.60)\end{array}$ & $\begin{array}{l}150 \\
0.98 \\
(0.57,3.00)\end{array}$ & $\begin{array}{l}136 \\
1.00 \\
(0.51,1.82)\end{array}$ \\
\hline
\end{tabular}

significant effect on the proportion of patients with at least a 20 or $30 \%$ decline in eGFR. However, significantly fewer patients in the treatment-naïve versus treatment-experienced group and in the group with no prior ADV therapy versus prior ADV therapy had an eGFR value of $<60 \mathrm{~mL} / \mathrm{min} / 1.73 \mathrm{~m}^{2}$ for at least one post-baseline visit ( $P<0.001$ for both).

Renal endpoints were observed in approximately $3 \%$ of patients: five patients had a serum creatinine increase of at least $0.5 \mathrm{mg} / \mathrm{dL}$ from baseline and two patients had a decreased creatinine clearance. Three cases of renal failure, two cases of renal impairment, and two cases of renal tubular dysfunction were reported as mild or moderate AEs. None of these patients had a reported history of renal impairment. One patient had been treated previously with ADV and LAM, one had been treated previously with ADV, two had been treated previously with ADV and LAM with LAM therapy continuing during the study. One patient had diabetes, two had hypercholesterolemia, and two were of older age (67 years and 72 years). TDF was discontinued in all patients. No renal-related serious AEs were reported.

\section{Major Liver-Associated Events}

Two cases of confirmed HCC and three cases of suspected HCC arose during the course of the study (months 3 and 12, and months 24 and 36, respectively). All patients were reported to have cirrhosis at baseline; both patients with confirmed HCC also had clinical signs or symptoms of advanced liver disease at baseline (esophageal varices in one patient; esophageal varices and ascites in the second). Two patients died due to complications of end-stage liver disease (hepatic encephalopathy $n=1$; spontaneous bacterial peritonitis $n=1$ ). Neither death was considered to be related to $\mathrm{TDF}$.

\section{Discussion}

In this study of $\mathrm{CHB}$ patients managed in routine clinical practice in France, treatment with TDF resulted in sustained virologic suppression. Virologic suppression was maintained over 36 months, irrespective of HBeAg status 
Table 6 Change in estimated glomerular filtration rate from baseline according to prior treatment status

\begin{tabular}{|c|c|c|c|c|}
\hline \multirow[t]{2}{*}{ Treatment group } & \multirow{2}{*}{$\begin{array}{l}\text { Baseline, } \\
(n)\end{array}$} & \multicolumn{3}{|c|}{ Change in eGFR (CKD-EPI) from baseline to: } \\
\hline & & $\begin{array}{l}\text { Month } 12 \text {, } \\
n, \text { median (range) }(\mathrm{mL} / \mathrm{min} / \\
\left.1.73 \mathrm{~m}^{2}\right)\end{array}$ & $\begin{array}{l}\text { Month } 24 \text {, } \\
n, \text { median (range) }(\mathrm{mL} / \mathrm{min} / \\
\left.1.73 \mathrm{~m}^{2}\right)\end{array}$ & $\begin{array}{l}\text { Month } 36 \text {, } \\
n, \text { median (range) }(\mathrm{mL} / \mathrm{min} / \\
\left.1.73 \mathrm{~m}^{2}\right)\end{array}$ \\
\hline \multirow[t]{4}{*}{ Overall } & \multirow[t]{4}{*}{360} & 249 & 217 & 204 \\
\hline & & -0.67 & -0.60 & -2.61 \\
\hline & & $(-41.5,38.54)$ & $(-61.03,37.86)$ & $(-48.78,34.91)$ \\
\hline & & $P=0.044$ & $P=0.681$ & $P=0.033$ \\
\hline \multirow[t]{4}{*}{ Treatment-naive } & \multirow[t]{4}{*}{143} & 91 & 79 & 75 \\
\hline & & -0.77 & -1.50 & -5.55 \\
\hline & & $(-37.91,22.00)$ & $(-36.02,29.86)$ & $(-48.78,34.54)$ \\
\hline & & $P=0.015$ & $P=0.240$ & $P=0.009$ \\
\hline \multirow{4}{*}{$\begin{array}{l}\text { Treatment- } \\
\text { experienced }\end{array}$} & \multirow[t]{4}{*}{217} & 158 & 138 & 129 \\
\hline & & -0.11 & 0.37 & -1.69 \\
\hline & & $(-41.05,38.54)$ & $(-61.03,37.86)$ & $(-40.78,34.91)$ \\
\hline & & $P=0.48$ & $P=0.762$ & $P=0.536$ \\
\hline \multirow[t]{4}{*}{ Prior ADV } & \multirow[t]{4}{*}{157} & 117 & 101 & 101 \\
\hline & & 0.03 & 1.18 & -1.02 \\
\hline & & $(-41.05,38.54)$ & $(-61.03,37.86)$ & $(-38.50,33.87)$ \\
\hline & & $P=0.534$ & $P=0.700$ & $P=0.888$ \\
\hline \multirow[t]{4}{*}{ No prior $A D V$} & \multirow[t]{4}{*}{203} & 132 & 116 & 103 \\
\hline & & -0.72 & -1.20 & -5.55 \\
\hline & & $(-37.91,33.18)$ & $(-50.07,29.86)$ & $(-48.78,34.91)$ \\
\hline & & $P=0.032$ & $P=0.327$ & $P=0.008$ \\
\hline
\end{tabular}

$A D V$ adefovir, $C K D$-EPI chronic kidney disease epidemiology collaboration, $e G F R$ estimated glomerular filtration rate $P$ values calculated using Fisher's exact test (two-sided)

(A)

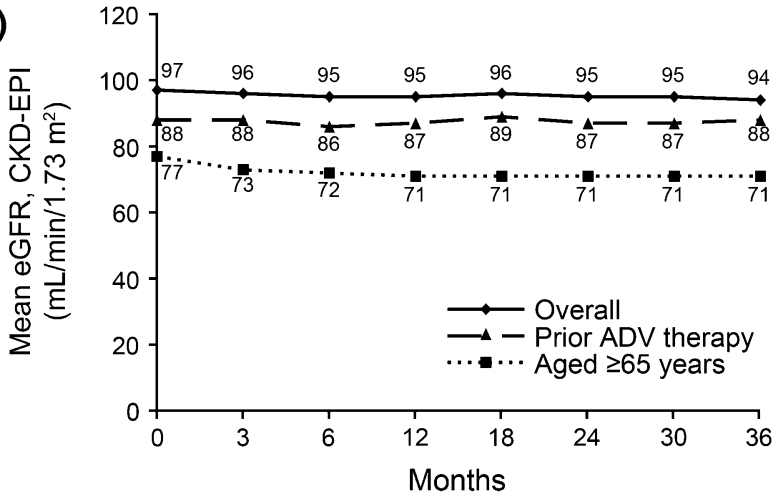

Patients with available data

$\begin{array}{lrrrrrrrr}\text { Overall } & 360 & 294 & 306 & 288 & 271 & 259 & 241 & 243 \\ \text { Aged } \geq 65 \text { years } & 36 & 30 & 33 & 36 & 32 & 30 & 25 & 24 \\ \text { Prior ADV therapy } & 157 & 121 & 128 & 128 & 125 & 112 & 107 & 113\end{array}$

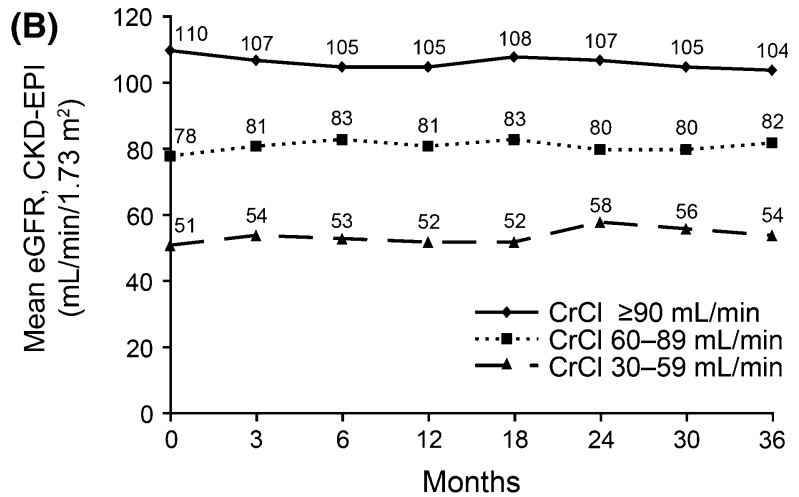

Patients with available data

$\begin{array}{lllllllll}\mathrm{CrCl} \geq 90 \mathrm{~mL} / \mathrm{min} & 238 & 173 & 165 & 158 & 145 & 136 & 126 & 130\end{array}$

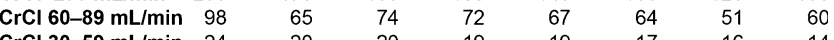

Fig. 2 Mean estimated glomerular filtration rate. a By age and treatment history; b by baseline creatinine clearance $(\mathrm{CrCl})$ category. $A D V$ adefovir, $C K D$-EPI chronic kidney disease epidemiology collaboration, $\mathrm{CrCl}$ creatinine clearance, $e G F R$ estimated glomerular filtration rate

or treatment history. In this diverse patient population, treatment was well tolerated with a safety profile similar to that reported in clinical trials. In addition, efficacy data from this study compare favorably to those reported in the pivotal clinical trials of TDF in CHB.
The diversity of the patient population in the VIREAL cohort compared with that in clinical trials is reflected in the wide variation of baseline parameters including ALT and viral load, the varied geographical origin of the patients, and the high proportion of patients with reported 
Table 7 Proportion of patients with a decline in estimated glomerular filtration rate of $\geq 20 \%$ compared with baseline, $\geq 30 \%$ compared with baseline and eGFR values $<60 \mathrm{~mL} / \mathrm{min} / 1.73 \mathrm{~m}^{2}$

\begin{tabular}{|c|c|c|c|c|c|}
\hline \multirow[t]{2}{*}{ Proportion of patients with } & \multicolumn{5}{|c|}{ Treatment group } \\
\hline & $\begin{array}{l}\text { Overall } \\
N=440\end{array}$ & $\begin{array}{l}\text { Treatment-naïve } \\
n=182\end{array}$ & $\begin{array}{l}\text { Treatment-experienced } \\
n=258\end{array}$ & $\begin{array}{l}\text { Prior ADV } \\
n=179\end{array}$ & $\begin{array}{l}\text { No Prior ADV } \\
n=261\end{array}$ \\
\hline $\begin{array}{l}\text { eGFR decline } \geq 20 \% \text { versus baseline, } \\
n(\%)\end{array}$ & $65(15)$ & $\begin{array}{l}22(12) \\
P=0.220\end{array}$ & $43(17)$ & $\begin{array}{l}31(17) \\
P=0.221\end{array}$ & $34(13)$ \\
\hline $\begin{array}{l}\text { eGFR decline } \geq 30 \% \text { versus baseline, } \\
n(\%)\end{array}$ & $26(6)$ & $\begin{array}{l}8(4) \\
P=0.308\end{array}$ & $18(7)$ & $\begin{array}{l}10(6) \\
P=1.00\end{array}$ & $16(6)$ \\
\hline $\begin{array}{l}\mathrm{eGFR}<60 \mathrm{~mL} / \mathrm{min} / 1.73 \mathrm{~m}^{2}, \\
n(\%)\end{array}$ & $48(11)$ & $\begin{array}{l}3(2) \\
P<0.001\end{array}$ & 45 (17) & $\begin{array}{l}35(20) \\
P<0.001\end{array}$ & $13(5)$ \\
\hline
\end{tabular}

$A D V$ adefovir, $e G F R$ estimated glomerular filtration rate

$P$ values calculated using Fisher's exact test (two-sided)

comorbidities. Despite this, the efficacy data from the current study compare favorably to those reported in the pivotal clinical trials of TDF in CHB. Following the initial randomized study period of 48 weeks, patients included in the pivotal clinical trials of TDF were enrolled in an openlabel study and treated for 7 additional years. After 26 months of treatment with TDF, $99 \%$ of $\mathrm{HBeAg}-$ patients and $93 \%$ of $\mathrm{HBeAg}+$ patients achieved $\mathrm{HBV}$ DNA $<69 \mathrm{IU} / \mathrm{mL}$ [13] in the on-treatment population, which is similar to that included in VIREAL. Further data have demonstrated that virologic response is maintained to 5 years, with $99 \%$ of $\mathrm{HBeAg}-$ and $97 \%$ of $\mathrm{HBeAg}+$ patients achieving HBV DNA $<29 \mathrm{IU} / \mathrm{mL}$ [14]. Recently presented 8-year data from this study show that this response is maintained, with a good safety profile and no evidence of virologic resistance [15].

Our data are similar to those reported in a prospective/ retrospective real-world European study including 374 treatment-naïve patients, where $97 \%$ of patients had undetectable HBV DNA (PCR negative) after 4 years of TDF treatment [16]. Patients in this European cohort and the majority of patients in the pivotal clinical trials were treatment-naive whereas around half of the patients in the VIREAL cohort were treatment-experienced.

By month 36 of the current study, $94 \%$ of treatmentexperienced patients achieved HBV DNA $<69 \mathrm{IU} / \mathrm{mL}$, including all 18 patients with resistance-associated variants at baseline. These results are consistent with data from a randomized trial of TDF or TDF/emtricitabine in patients who previously had an incomplete response to ADV [19]. This study demonstrated that response was not influenced by the presence of ADV- or LAM-associated mutations. In contrast, retrospective analysis of patients treated in Germany and The Netherlands found that although LAM resistance did not influence antiviral response, the presence of ADV resistance impaired TDF efficacy (100 vs. $52 \%$ probability of HBV DNA $<69 \mathrm{IU} / \mathrm{mL}$, respectively) [20]. The variability in these results demonstrates that further research is required before the relationship between ADV resistance and TDF response is fully understood.

Numerous studies have shown an association between HBV DNA levels and disease progression [5, 8] and that long-term HBV DNA suppression can reduce serious liverrelated sequalae $[14,21]$ reinforcing the importance of HBV DNA suppression in the treatment of CHB.

Overall, $78 \%$ of VIREAL patients had normal ALT levels after 36 months of TDF treatment, again similar to that seen in pivotal trials $[3,12,15]$. Serologic response in VIREAL was also similar to that seen in clinical trials, with $45 \%$ of $\mathrm{HBeAg}+$ patients losing HBeAg in VIREAL compared with $34 \%$ in the clinical trial population after 3 years [13]. In all, 14 patients in VIREAL lost HBsAg during the course of the study, and seven of these patients also seroconverted to anti-HBs. Interestingly, these patients were predominantly $\mathrm{HBeAg}-$ at baseline, while all except one patient who showed HBsAg loss/ seroconversion in the clinical trial population were $\mathrm{HBeAg}+$. This may partly result from the proportion of $\mathrm{HBeAg}$ - patients in this cohort compared with the clinical trial population.

TDF was well tolerated over 36 months in VIREAL, with a safety profile similar to that reported in clinical trials. Treatment-related serious AEs were low, and the majority of patients stayed on TDF treatment until their last visit. There was no statistical difference in the number of AEs related to TDF reported in treatmentnaïve and treatment-experienced patients. Although there was a slight decline in mean serum creatinine, $\mathrm{CrCl}$, and eGFR, statistical comparison to baseline should be viewed with caution due to the high proportion of missing data. Furthermore, a decrease in eGFR is expected in patients over time due to aging. We observed 
that significantly fewer treatment-naïve patients had an eGFR value of $<60 \mathrm{~mL} / \mathrm{min} / 1.73 \mathrm{~m}^{2}$ compared with treatment-experienced patients. This could be due to the fact that treatment-experienced patients have received treatment for a longer duration than patients who were receiving $\mathrm{TDF}$ as their first treatment. While serum creatinine levels are commonly used markers of renal function, other urinary and serum proteins may be earlier, more accurate markers of renal toxicity [22]. However, testing of such biomarkers is not routinely used in clinical practice, and creatinine clearance was therefore used in this real-life study to monitor renal function. In all, only seven cases of renal AEs were reported, all of which were of mild-to-moderate intensity, and were managed by TDF discontinuation.

Our study adds to the increasing data on the use of TDF during pregnancy. In VIREAL, treatment with TDF during pregnancy, including during the first trimester, was not associated with any AEs during pregnancy, complications during labor, neonatal complications, or birth defects. TDF has been assigned pregnancy category B by the Food and Drug Administration, compared with category $\mathrm{C}$ for LAM, ADV, and ETV. A recent review examining data on the use of TDF in pregnancy in both HIV and HBV infection [23] together with that from the 1800 pregnancies included in the Antiretroviral Pregnancy Registry, concluded that the safety data for TDF during pregnancy are generally reassuring for pregnancy outcomes and for lack of congenital or other severe anomalies in exposed infants.

The limitations of this study are those generally related to non-interventional, uncontrolled, observational studies. There was a variable amount of missing data which was particularly notable for some parameters. The reasons for this loss may include the treating physician not performing certain tests routinely, patients being lost to follow-up, or database entry errors. In addition, sites utilized their local laboratory for testing which means that inter-laboratory variation is possible. The data presented here is reflective of the practice of the clinicians included in the study and their individual monitoring procedures. As a result, some parameters of interest, such as bone mineral density and bone biomarkers, which are known to be associated with antiretroviral therapy [24], were not specifically assessed in this study. However, the main strength of the study is the diversity of the patient population meaning the results are relevant to real-world patients and to other countries with similar management strategies and HBV demographics.

In conclusion, TDF shows significant and sustained antiviral activity against $\mathrm{HBV}$ and a favorable safety and tolerability profile in a diverse population of patients managed in routine clinical practice, including treatment- experienced patients, older patients, and patients with advanced liver disease or renal insufficiency. The effectiveness and safety results of TDF in clinical practice are similar to those reported in clinical trials.

Acknowledgments Medical writing assistance, supported by Gilead Sciences, was provided by Liesje Quine, Ph.D., Elements Communications Ltd, Westerham, UK.

Funding This study was supported by Gilead Sciences. The study sponsors were involved in the design of the study and in the collection and analysis of data. The decision to submit the manuscript for publication was entirely at the discretion of the authors.

Author contributions All authors recruited patients and collected data or were involved in data interpretation. All authors were involved in drafting the manuscript and critical revision of the manuscript for important intellectual content, and all authors approved the final version of the manuscript.

\section{Compliance with ethical standards}

Conflict of interest P.M. is a speaker and investigator for BMS, Boehringer-Ingelheim, Tibotec, Janssen, Gilead, Roche, and Merck. F.Z. has served as an investigator for Gilead and a consultant/speaker for Gilead and Bristol-Myers Squibb. C.H. has served as a consultant/ speaker for Roche, Bristol-Myers Squibb, Merck, Janssen, AbbVie, and Gilead Sciences. X.C. has served as a consultant/speaker for Gilead, BMS, and Janssen-Cilag. M.B. has received research grants from Bayer, Gilead Sciences, Janssen and Merck. He has served as an advisory board member and speaker for AbbVie, Bristol-Myers Squibb, Gilead Sciences, GlaxoSmithKline, Idenix, Janssen, Merck, Roche and Vertex and is a consultant/speaker for Gilead. J.P.Z. consults and is on the speakers' bureau for Gilead, Bristol-Myers Squibb, Janssen, Siemens, and MSD and he consults for AbbVie. S.M.C. has received fees for participation in advisory boards for Novo Nordisk and Gilead, and for lectures from AstraZeneca, Bayer, Boehringer Ingelheim, Bristol-Myers Squibb, Eli Lilly, Euthérapie, GlaxoSmithKline, Gilead, Janssen, Lundbeck, MSD, Merck Sharp and Dohme, Novartis, Novo Nordisk, Otsuka Pharmaceutical France, Pfizer, Sanofi, Servier, and Wyeth. J.F.C. is a board member of Gilead. P.P. is a Gilead employee and has Stock-Options and RSU. O.L. is a Gilead employee. V.T. and C.S. were Gilead employees at the time of submission of this manuscript but are no longer working for Gilead. B.R., A.P., R.T., J.D., D.O., G.P.P., G.R., and D.L., have no conflicts of interest to declare.

Ethical approval For this type of study formal consent is not required. The study was conducted in accordance with Good Epidemiological Practice guidelines, was approved by the French Medical Board, and was authorized by the National Computers and Privacy Commission.

Informed consent Patients gave written consent for access to their medical records.

Open Access This article is distributed under the terms of the Creative Commons Attribution-NonCommercial 4.0 International License (http://creativecommons.org/licenses/by-nc/4.0/), which permits any noncommercial use, distribution, and reproduction in any medium, provided you give appropriate credit to the original author(s) and the source, provide a link to the Creative Commons license, and indicate if changes were made. 


\section{Appendix: VIREAL Group}

Prof. Alric, Toulouse; Dr. Amiot, Paris; Dr. Arpurt, Avignon; Dr. Barthe, Basse-Terre (Guadeloupe); Dr. Beorchia, Lyon; Prof.. Bernard, Bordeaux; Dr. Bernard-Chabert, Reims; Dr. Bismuth, Montpellier; Prof. Botta-Fridlund, Marseille; Dr. Bourliere, Marseille; Dr. Bramli, Avignon; Prof. Bresson-Hadni, Besançon; Prof. Bronowicki, Vandoeuvre Les Nancy; Prof. Cadranel, Creil; Dr. Causse, Orléans; Dr. Constant, Toulon; Dr. Cuissard, Le Port (La Réunion); Prof. Dao, Caen; Dr. Delasalle, Grasse; Dr. Desmorat, Toulouse; Prof. Dumortier, Lyon; Dr. Fontanges, Bourgoin-Jallieu; Dr. Fouchard-Hubert, Angers; Prof. Ganne, Bondy; Dr. Grangé, Paris; Prof. Guyader, Rennes; Dr. Habersetzer, Strasbourg; Dr. Hanslik, Montpellier; Prof. Hezode, Créteil; Prof. Hillon, Dijon; Dr. Joseph-Reinette, Argenteuil; Dr. Labarriere, Orléans; Pro Larrey, Montpellier; Dr. Lascoux, Paris; Prof. de Ledinhen, Pessac; Prof. Loustaud-Ratti, Limoges; Dr. Louvel, Cayenne (Guyane); Prof. Lucidarme, Lomme; Prof. Marcellin, Clichy; Dr. Marois, Eaubonne; Prof. Di Martino, Besançon; Prof. Mathurin, Lille; Prof. Nguyen Khac, Amiens; Dr. Ouzan, Saint Laurent du Var; Prof. Pageaux, Montpellier; Dr. Pauwels, Gonesse; Dr. Pintado, Paris; Prof. Pol, Paris; Dr. Rabbe, Metz; Prof. Ratziu, Paris; Dr. Renard, Argenteuil; Dr. Riachi, Rouen; Dr. Roche, Villejuif; Prof. Roulot, Bobigny; Dr. Saillard, Pointe A Pitre; Dr. Truchi, Nice; Prof. Zarski, Grenoble; Prof. Zoulim, Lyon.

\section{References}

1. World Health Organization. Hepatitis B Fact Sheet No 204. Updated July 2014. http://www.who.int/mediacentre/factsheets/ fs204/en/. Accessed June 2015.

2. Chu JJ, Wörmann T, Popp J, et al. Changing epidemiology of hepatitis B and migration-a comparison of six Northern and North-Western European countries. Eur J Public Health. 2013;23:642-647.

3. Zarski JP. Epidémiologie de l'hépatite chronique B. Presse Med. 2006;35:304-307.

4. Marcellin P, Pequignot F, Delarocque-Astagneau E, et al. Mortality related to chronic hepatitis $\mathrm{B}$ and chronic hepatitis $\mathrm{C}$ in France: evidence for the role of HIV coinfection and alcohol consumption. J Hepatol. 2008;48:200-207.

5. Chen G, Lin W, Shen F, Iloeje UH, London WT, Evans AA. Past HBV viral load as predictor of mortality and morbidity from HCC and chronic liver disease in a prospective study. Am J Gastroenterol. 2006;101:1797-1803.

6. Chen CJ, Yang HI, Su J, et al. Risk of hepatocellular carcinoma across a biological gradient of serum hepatitis B virus DNA level. JAMA. 2006;295:65-73.
7. Iloeje UH, Yang HI, Su J, Jen CL, You SL, Chen CJ. Predicting cirrhosis risk based on the level of circulating hepatitis B viral load. Gastroenterology. 2006;130:678-686.

8. Iloeje UH, Yang HI, Jen CL, et al. Risk and predictors of mortality associated with chronic hepatitis B infection. Clin Gastroenterol Hepatol. 2007;5:921-931.

9. European Association for the Study of the Liver. EASL clinical practice guidelines: management of chronic hepatitis B. $J$ Hepatol. 2012;57:167-185.

10. Dhumeaux D. Prise en charge des personnes infectées par les virus de l'hépatite $B$ ou de l'hépatite C. Rapport de Recommandations 2014. http://www.sante.gouv.fr/IMG/pdf/Rapport_ Prise_en_charge_Hepatites_2014.pdf. Accessed June 2015.

11. Lok AS, McMahon BJ. Chronic hepatitis B: update 2009. Hepatology. 2009;50:661-662.

12. Marcellin P, Heathcote EJ, Buti M, et al. Tenofovir disoproxil fumarate versus adefovir dipivoxil for chronic hepatitis B. N Engl J Med. 2008;359:2442-2455.

13. Heathcote EJ, Marcellin P, Buti M, et al. Three-year efficacy and safety of tenofovir disoproxil fumarate treatment for chronic hepatitis B. Gastroenterology. 2011;140:132-143.

14. Marcellin P, Gane E, Buti M, et al. Regression of cirrhosis during treatment with tenofovir disoproxil fumarate for chronic hepatitis B: a 5-year open-label follow-up study. Lancet. 2013;381: 468-475.

15. Marcellin P, Gane EJ, Flisiak R, et al. Long term treatment with tenofovir disoproxil fumarate for chronic hepatitis B infection is safe and well tolerated and associated with durable virologic response with no detectable resistance: 8 year results from two phase 3 trials. Hepatology. 2014;60:313A.

16. Lampertico P, Soffrendi R, Yurdaydin C, et al. Four years of tenofovir monotherapy for NUC naïve field practice European patients suppresses HBV replication in most patients with a favourable renal safety profile but does not prevent $\mathrm{HCC}$ in patients with or without cirrhosis. Hepatology. 2013;58:653A.

17. van Bömmel F, Zoutendijk R, de Man R, et al. A European field study of the efficacy and safety of tenofovir disoproxil fumarate (TDF) monotherapy in patients with prior failure to other nucleoside/nucleotide analogues. J Hepatol. 2012;57:S544.

18. Girerd X, Hanon O, Anagnostopoulos K, Ciupek C, Mourad JJ, Consoli S. Assessment of antihypertensives compliance using a self-administered questionnaire: development and use in hypertension clinics. Presse Med. 2001;30:1044-1048.

19. Berg T, Marcellin P, Zoulim F, et al. Tenofovir is effective alone or with emtricitabine in adefovir-treated patients with chronichepatitis B virus infection. Gastroenterology. 2010;139:12071217.

20. van Bömmel F, de Man RA, Wedemeyer H, et al. Long-term efficacy of tenofovir monotherapy for hepatitis B virus-monoinfected patients after failure of nucleoside/nucleotide analogues. Hepatology. 2010;51:73-80.

21. Liaw YF, Sung JJ, Chow WC, et al. Lamivudine for patients with chronic hepatitis B and advanced liver disease. $N$ Engl J Med. 2004:351:1521-1531.

22. Lock E. Sensitive and early markers of renal injury: where are we and what is the way forward? Toxicol Sci. 2010;116:1-4.

23. Wang L, Kourtis AP, Ellington S, Legardy-Williams J, Bulterys M. Safety of tenofovir during pregnancy for the mother and fetus: a systematic review. Clin Infect Dis. 2013;57:1773-1781.

24. Fontana RJ. Side effects of long-term oral antiviral therapy for hepatitis B. Hepatology. 2009;49(Suppl):S185-S195. 